University of Nebraska - Lincoln

DigitalCommons@University of Nebraska - Lincoln

Faculty Publications: Department of Entomology

Entomology, Department of

February 2005

\title{
Immunological Assessment of an Insecticide Resistance- Associated Esterase in the Western Corn Rootworm
}

\author{
Xuguo Zhou \\ University of Florida, Gainesville \\ Michael E. Scharf \\ University of Florida, Gainesville \\ Lance J. Meinke \\ University of Nebraska-Lincoln, Imeinke1@unl.edu \\ Laurence D. Chandler \\ USDA-ARS Northern Plains Area Office, Fort Collins, Colorado \\ Blair D. Siegfried \\ University of Nebraska-Lincoln, bsiegfried1@ufl.edu
}

Follow this and additional works at: https://digitalcommons.unl.edu/entomologyfacpub

Part of the Entomology Commons

Zhou, Xuguo; Scharf, Michael E.; Meinke, Lance J.; Chandler, Laurence D.; and Siegfried, Blair D., "Immunological Assessment of an Insecticide Resistance-Associated Esterase in the Western Corn Rootworm" (2005). Faculty Publications: Department of Entomology. 3.

https://digitalcommons.unl.edu/entomologyfacpub/3

This Article is brought to you for free and open access by the Entomology, Department of at DigitalCommons@University of Nebraska - Lincoln. It has been accepted for inclusion in Faculty Publications: Department of Entomology by an authorized administrator of DigitalCommons@University of Nebraska - Lincoln. 


\title{
Immunological Assessment of an Insecticide Resistance-Associated Esterase in the Western Corn Rootworm
}

\author{
Xuguo Zhou, ${ }^{1}$ Michael E. Scharf, ${ }^{1}$ Lance J. Meinke, ${ }^{2}$ Laurence D. Chandler, ${ }^{3}$ and \\ Blair D. Siegfried ${ }^{2 *}$ \\ In previous investigations, we have determined that organophosphate resistance in the western corn rootworm, Diabrotica virgifera \\ virgifera, is at least partially attributed to a group of non-specific carboxylesterases referred to as group II. Antiserum raised \\ against a purified 66-kDa group II esterase is specific for the denatured enzyme. This antiserum reacts similarly with both beetle \\ homogenates from resistant and susceptible populations, although there is much higher signal intensity in immunoblots of resis- \\ tant relative to susceptible beetles. These results suggest that overproduction of group II esterases is the underlying basis of \\ esterase-mediated resistance in D. v. virgifera by demonstrating that (1) group II esterases are immunologically indistinguishable \\ between the resistant and susceptible populations, and (2) the intensity differences are due to increased group II esterase proteins \\ in the resistant population. The diagnostic potential of immunological-based assays was tested with a traditional diagnostic \\ concentration bioassay and a biochemical-based native PAGE assay. Significant correlations were observed among all three diag- \\ nostic assays (regression coefficients ranging from 0.95 to 0.96). These results demonstrate the importance of the 66-kDa protein \\ as a resistance-associated biochemical marker, thus emphasizing the potential for 66-kDa protein-targeted immunoassays in \\ resistance monitoring programs. Arch. Insect Biochem. Physiol. 58:157-165, $2005 . \quad$ c) 2005 Wiley-liss, Inc.
}

KEYworos: immunoassay; esterase; insecticide resistance monitoring; Diabrotica virgifera virgifera

\section{INTRODUCTION}

The western corn rootworm, Diabrotica virgifera vigifera LeConte, is the most economically and environmentally important insect pest of maize in North America (Chang, 1973; Levine and Oloumi-Sadeghi, 1991). Synthetic insecticides and crop rotation have been the traditional rootworm management strategies for many years. However, the remarkable capacity of this insect to evolve resistance has resulted in the failure of both broad spectrum insecticides (Levine and Oloumi-Sadeghi, 1991; Meinke et al., 1998) and crop rotation (Levine et al., 2002) as rootworm management options. Widespread resistance of $D$. $v$. virgifera to organochlorine insecticides in the 1950s resulted in the adoption of adult control in certain areas of Nebraska (Meinke et al., 1998). Adult control, which involves the application of foliar insecticides to suppress adult populations and reduce egg laying to decrease the population density in the following season (Pruess et al., 1974), has been highly effective over several decades. Microencapsulated methyl-parathion (Penncap-M ${ }^{\circledR}$, Elf Atochem North America, Inc., Philadelphia, PA) has been the most commonly used organophosphate insecticide to control adult

\footnotetext{
'Department of Entomology and Nematology, University of Florida, Gainesville

${ }^{2}$ Department of Entomology, University of Nebraska-Lincoln

${ }^{3}$ USDA-ARS Northern Plains Area Office, Fort Collins, Colorado

Contract grant sponsor: USDA; Contract grant numbers: 58-5447-6-116, 00-52103-9699.

*Correspondence to: B. Siegfried, 202 Plant Industry Building, Department of Entomology, University of Nebraska, Lincoln, NE 68583.

E-mail: bsiegfried1@unl.edu
}

Received 14 July 2004; Accepted 12 November 2004

(C) 2005 Wiley-Liss, Inc.

DOI: 10.1002/arch.20040

Published online in Wiley InterScience (www.interscience.wiley.com) 
D. v. virgifera in Nebraska because of its low cost and relatively long persistence. However, the repetitive application of methyl-parathion in continuous corn fields led to detectable levels of organophosphate resistance by the mid 1990s (Meinke et al., 1997).

Studies of organophosphate resistance mechanisms have revealed high levels of general esterase activity in resistant D. v. virgifera populations from across South-Central Nebraska (Zhou et al., 2002, 2003, 2004). Other evidence, such as in vivo metabolism experiments with ${ }^{14} \mathrm{C}$-labeled ethyl-parathion, and synergism bioassays with the esterase inhibitor DEF ( $S, S, S$,-tributyl phosphorotrithioate) indicated the involvement of esterase-mediated resistance in both larvae and adult $D$. $v$. virgifera (Miota et al., 1998; Wright et al., 2000).

Three distinct groups of esterase isozymes (I, II, and III) are identifiable by native polyacrylamide gel electrophoresis (PAGE). Of the three esterase groups, group II esterases are overproduced in resistant individuals (Zhou et al., 2002). Elevated activity of group II esterase isozymes is highly correlated with resistance and these enzymes provide a reliable biochemical marker for the detection of methyl-parathion resistance in individual rootworms (Zhou et al., 2002, 2003). Recent investigations of partially purified group II esterases and the resulting physical, kinetic, and insecticide inhibition properties all suggested the overproduction of resistance-associated esterase as the molecular basis of organophosphate resistance in $D . v$. virgifera (Zhou et al., 2004). In this study, we report on the development of immunoassays for detection of the group II esterase from both resistant and susceptible D. v. virgifera populations. These results provide insight into the molecular basis of resistance and diagnostic potential of group II esterase antiserum for detection of resistance among field populations.

\section{MATERIALS AND METHODS}

\section{D. v. virgifera Populations}

Three populations were collected in Nebraska during the summer of 1996 and 1997. The Saun- ders County population was collected from areas where adult management is not practiced and has previously been shown to be highly susceptible to methyl-parathion (Meinke et al. 1998). In contrast, the resistant Phelps County and York County populations originated from areas where continuous corn production and adult control practice have been used for more than two decades and where field control failures had become common. Previous bioassays with methyl-parathion indicated 12.5- and 16.4-fold higher $\mathrm{LD}_{50}$ values in the York and Phelps populations, respectively.

Field populations of adult rootworms used in diagnostic bioassays were collected in Nebraska and Colorado during the summer of 1999 before seasonal insecticide applications had begun. The field populations were maintained in the laboratory at ambient temperature with a $14: 10 \mathrm{~h}(\mathrm{~L}: \mathrm{D})$ photoperiod and were fed a standard diet of head lettuce and sweet corn before being frozen at $-80^{\circ} \mathrm{C}$ and stored for subsequent experiments.

\section{Chemicals}

DEAE Sepharose, hydroxyapatite, and all other reagents and solvents were purchased from Sigma Chemical Co. (St. Louis, MO) unless stated otherwise. Electrophoresis reagents were purchased from Bio-Rad Laboratories (Hercules, CA). Polyvinyldiene difluoride (PVDF) membrane was from Millipore (Boston, MA). The protein assay kit was from Pierce (Rockford, IL). The methyl-parathion (99\%) used in diagnostic concentration bioassays was purchased from Chem Service (West Chester, PA).

\section{Diagnostic Concentration Bioassay}

Bioassays were conducted in 20-ml glass scintillation vials containing a diagnostic concentration of $0.5 \mu \mathrm{g}$ methyl-parathion per vial (Zhou et al., 2002). Insecticide dilutions were prepared in acetone using technical grade methyl-parathion of $>99 \%$ purity. Vials were treated with $0.5 \mathrm{ml}$ of insecticide dilution and rolled until dry in a fume hood. For each population, 10 beetles of mixed sex were placed in 10 replicate vials (plus 2 ac- 
etone control vials). Vials containing beetles were held at $22^{\circ} \mathrm{C}$ in darkness for $4 \mathrm{~h}$, before mortality was scored based on a lack of coordinated movement by the beetles.

\section{Protein Purification and Polyclonal Antiserum Synthesis}

Resistance-associated group II esterases were partially purified from rootworm abdominal tissues as previously described by Zhou et al. (2004). Soluble proteins from abdominal homogenates were prepared by differential centrifugation (the homogenates were centrifuged at $10,000 \mathrm{~g}$ for $20 \mathrm{~min}$, and the resulting supernatants were filtered through glass wool, and then centrifuged at 100,000g for 1 h). Group II esterases were partially purified by sequential column chromatography (ion-exchange chromatography followed by hydroxyapatite chromatography). Following hydroxyapatite chromatography, fractions containing resistant and susceptible group II esterases were pooled, concentrated, and viewed on Coomassie-stained SDS-PAGE gels (Laemmli, 1970). Three predominant protein bands $(20-, 29-$, and $66-\mathrm{kDa})$ were present in greater quantities in the resistant preparation; two of them (29- and 66-kDa proteins) were chosen for development of antisera based on the size range of previously reported resistance-associated esterases (Zhou et al., 2004). Both the 29- and 66-kDa protein bands were purified to homogeneity through preparative electrophoresis involving zinc staining (Bio-Rad, Hercules, CA), excision, destaining and electro-elution (Bio-Rad 422 Electro-Eluter) as described by Zhou et al. (2004). After dialyzing against $5 \mathrm{mM}$ Tris buffer for $24 \mathrm{~h}$ at $4^{\circ} \mathrm{C}$ (to remove SDS), pure proteins were concentrated to approximately 50-100 $\mu \mathrm{l}$ and submitted to the University of Nebraska antibody core facility.

Polyclonal antisera against the purified 29- and $66-\mathrm{kDa}$ proteins were raised in New Zealand white rabbits and BALB/c mice, respectively (two animals each), by injecting the purified proteins three times bi-weekly. After the second injection of antigen for both rabbits and mice, microliter quantities $(\leq 20$ $\mu l)$ of serum were obtained and preliminary West- ern blots were performed to compare with pre-immune sera. This comparison enabled us to evaluate (1) if an immunological response was occurring and (2) if the antisera specifically recognized antigenic proteins. At 1 week after the last injection, the rabbit and mouse with the best immunological responses were sacrificed and their blood serum used as polyclonal antibody sources.

\section{Electrophoresis and Western Blot Analysis}

Native-PAGE was conducted on $7.5 \%$ resolving gels with 4\% stacking gels and a discontinuous trisglycine running buffer system. Volumes of supernatant containing $10 \mu \mathrm{g}$ protein were mixed with $1.5 \mu \mathrm{l}$ of loading buffer (tris-glycine running buffer containing $20 \%$ sucrose and $0.05 \%$ xylene cyanol) prior to loading onto gels. Electrophoresis was conducted at $4{ }^{\circ} \mathrm{C}$ and $120 \mathrm{~V}$ for $1.5 \mathrm{~h}$. Esterase bands were then visualized by incubating the gels in 100 $\mathrm{ml} 0.02 \mathrm{M}$ sodium phosphate buffer ( $\mathrm{pH}$ 7.0), with $2 \%(\mathrm{v} / \mathrm{v}) 30 \mathrm{mM} \alpha$-naphthyl acetate dissolved in acetone at $30^{\circ} \mathrm{C}$ for $15 \mathrm{~min}$ before adding $0.04 \%$ fast blue $\mathrm{BN}$ salt (tetrazotized O-dianisidine) (w/v).

Western blot analyses with denatured proteins were carried out following separation of $20 \mu \mathrm{g}$ denatured rootworm supernatant on 12\% SDS-PAGE gels (Laemmli, 1970). Proteins were transferred from gels to nitrocellulose membranes for $1 \mathrm{~h}$ at $100 \mathrm{~V}$ and $4^{\circ} \mathrm{C}$ using a wet-cell transfer apparatus (Bio-Rad, Hercules, CA). Transfer occurred in Trisglycine buffer containing $20 \% \mathrm{v} / \mathrm{v}$ methanol, and transfer was confirmed by reversible staining with Ponceau-S (Sigma, St. Louis, MO). Membranes were briefly washed in phosphate-buffered saline (PBS) and blocked overnight at $4^{\circ} \mathrm{C}$ in $20 \mathrm{ml}$ of PBS $+0.05 \% \mathrm{v} / \mathrm{v}$ Tween-20 (PBST) containing 15 $\mathrm{mg} / \mathrm{ml}$ non-fat dried milk (Bio-Rad). Membranes were then incubated for $1 \mathrm{~h}$ in PBST and primary antiserum prepared at either $1: 500$ or $1: 1,000 \mathrm{di}$ lutions, washed 3 times for $5 \mathrm{~min}$ in PBST, incubated $1 \mathrm{~h}$ in PBST and 1:1,000 goat anti-mouse (for the $66-\mathrm{kDa}$ antiserum detection) or goat antirabbit IgG (for the 29-kDa antiserum detection) alkaline phosphatase conjugate (Boehringer-Mannheim; Indianapolis, IN), washed 5 times for $5 \mathrm{~min}$ 
in PBST, and developed for 3-5 min in BCIP-NBT substrate (Sigma) to visualize antibody-conjugate. Immunoblots with native proteins were performed in a similar manner to that reported for denatured proteins, although the initial separation of proteins was done under non-denaturing conditions (Zhou et al., 2003).

\section{Diagnostic Assays}

Individual rootworm adults from 10 different populations that exhibited varying levels of susceptibility at a diagnostic methyl-parathion concentration (Zhou et al., 2003) were examined by both native-PAGE assays and Western blots using the $66-\mathrm{kDa}$ protein antiserum. In order to quantify esterase activities on the native-PAGE and immunological responses on the immunoblot, the relative intensity of staining was measured by densitometric scanning using a Gel Doc 2000 gel documentation system interfaced with Quantity One software (Bio-Rad). The diagnostic potential of the $66-\mathrm{kDa}$ protein antiserum was evaluated by the two-way regression analyses of diagnostic concentration bioassays, native PAGE assays, and immunoassays developed in this study. The appropriate summary statistics were analyzed by SAS PROC CORR (SAS Institute, 2001).

\section{RESULTS}

\section{Immunological Responses of the 29- and 66-kDa Protein Antiserum}

Examination of post-hydroxyapatite fractions by SDS PAGE revealed three predominant protein bands of approximately 66-, 29-, and 20-kDa that exhibited increased staining intensity in the resistant relative to the susceptible population (Fig. 1A). Western blot analyses of $66-\mathrm{kDa}$ protein antiserum under denaturing conditions revealed a single band corresponding in size to the purified $66-\mathrm{kDa}$ protein (Fig. 1B) in both resistant and susceptible populations. The immunological responses (staining intensity) of the $66-\mathrm{kDa}$ protein are clearly elevated in resistant York and Phelps County populations compared to the susceptible Saunders County population, and no differences between sexes were detected. This is consistent with the native-PAGE results shown in Figure $1 \mathrm{C}$. The antiserum to the 66-kDa protein apparently did not react with native proteins as Western blots of native gels did not reveal any bands (data not shown).

The 29-kDa protein antiserum cross-reacted with multiple proteins (20-, 29-, and 66-kDa) under denaturing conditions. Although increased signals were observed in resistant populations for the lower molecular weight proteins (20- and 29-kDa), such intensity differences were observed only in adult males (Fig. 1D). In contrast, the $66-\mathrm{kDa}$ protein was present in both males and females, and exhibited increased intensity in the resistant strain. In Western analysis of native gels with individual adult males and females (20 males and 20 females per population), the $29-\mathrm{kDa}$ antiserum readily discriminated between resistant and susceptible males, but not females (Fig. 2).

\section{Diagnostic Potential of the 66-kDa Protein Antiserum}

Ten populations exhibiting mortality ranging from 13.3 to $97.0 \%$ at a diagnostic methyl-parathion concentration (Table 1) were evaluated by both biochemical- and immunological-based diagnostic assays. Among the 10 populations, the staining intensity of group II esterase isoforms on native-PAGE (Fig. 3A) and the signal intensity of the $66-\mathrm{kDa}$ protein bands on immunoblots (Fig. 3C) increase incrementally in association with their resistance status. Regression analyses for comparisons of methyl-parathion percent diagnostic mortality (Table 1), relative intensity of group II esterases on native gels (Fig. 3B), and relative intensity of $66-\mathrm{kDa}$ protein band in immunoblots (Fig. 3D) are shown in Table 2. Regression analyses indicate a strong relationship $\left(r^{2}\right.$ values ranging from 0.95 to 0.96 ) among all three diagnostic assays. These results clearly document the importance of the $66-\mathrm{kDa}$ protein as a resistance-associated biochemical marker and the diagnostic potential of this 66-kDa protein antiserum. 


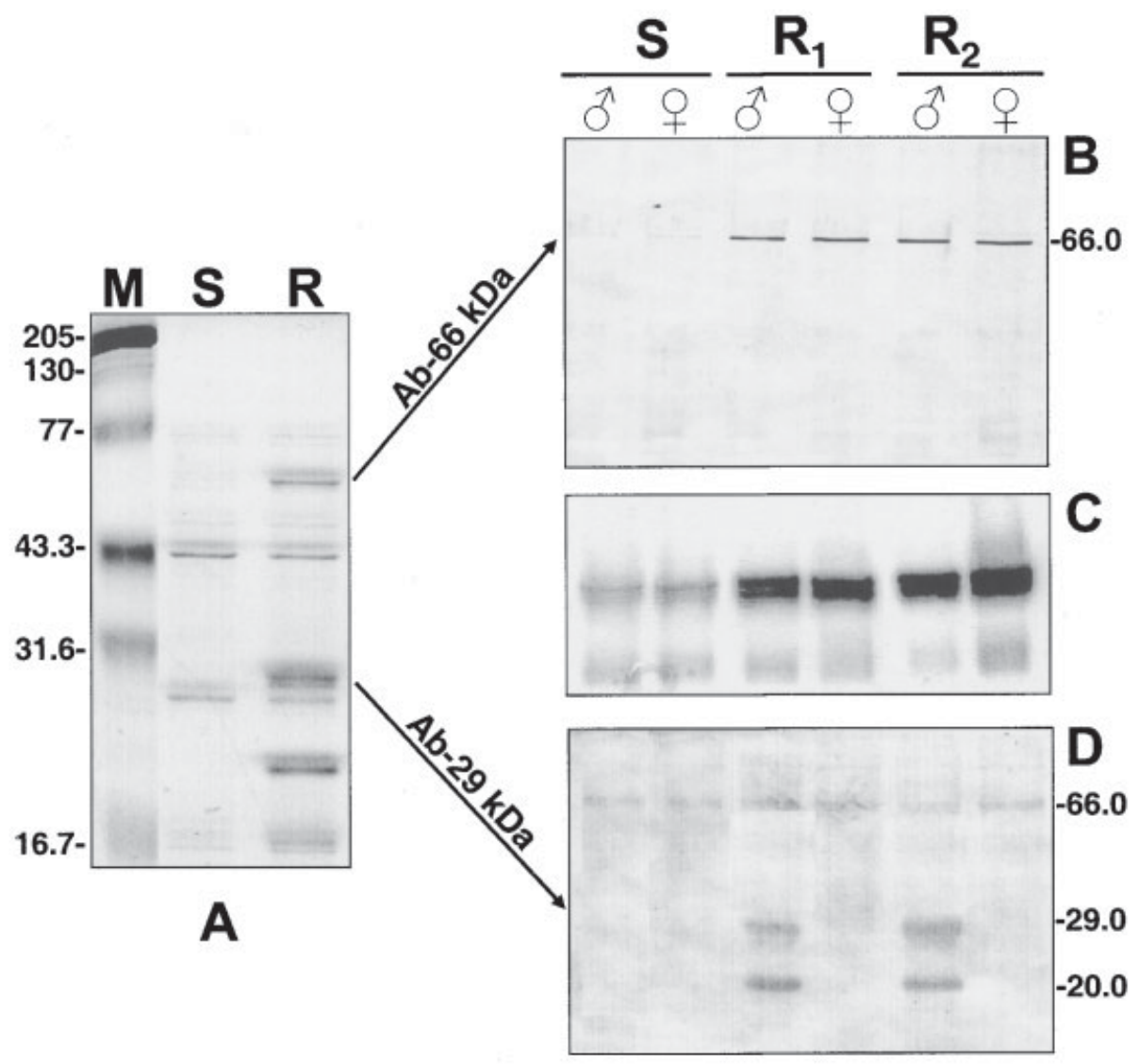

Fig. 1. Immunological reactions of the 29- and 66-kDa antisera with denatured proteins form resistant and susceptible D. $v$. virgifera. A: SDS PAGE stained with Coomassie blue to show partially purified group II esterases (post-ion exchange fractions). B: Western blot probed with 66-kDa antiserum C: Native PAGE stained to show esterase activity in crude homogenates. D: Western blot probed with 29-kDa antiserum. Abdominal tissues of 10 same-sex beetles ( $₫$ or $q$ ) from resistant York County $\left(\mathrm{R}_{1}\right)$, Phelps County $\left(R_{2}\right)$, and susceptible Saunders County (S) populations were used as enzyme sources for this study.

Saunders (S) York $\left(\mathbf{R}_{1}\right)$ Phelps $\left(\mathbf{R}_{\mathbf{2}}\right)$

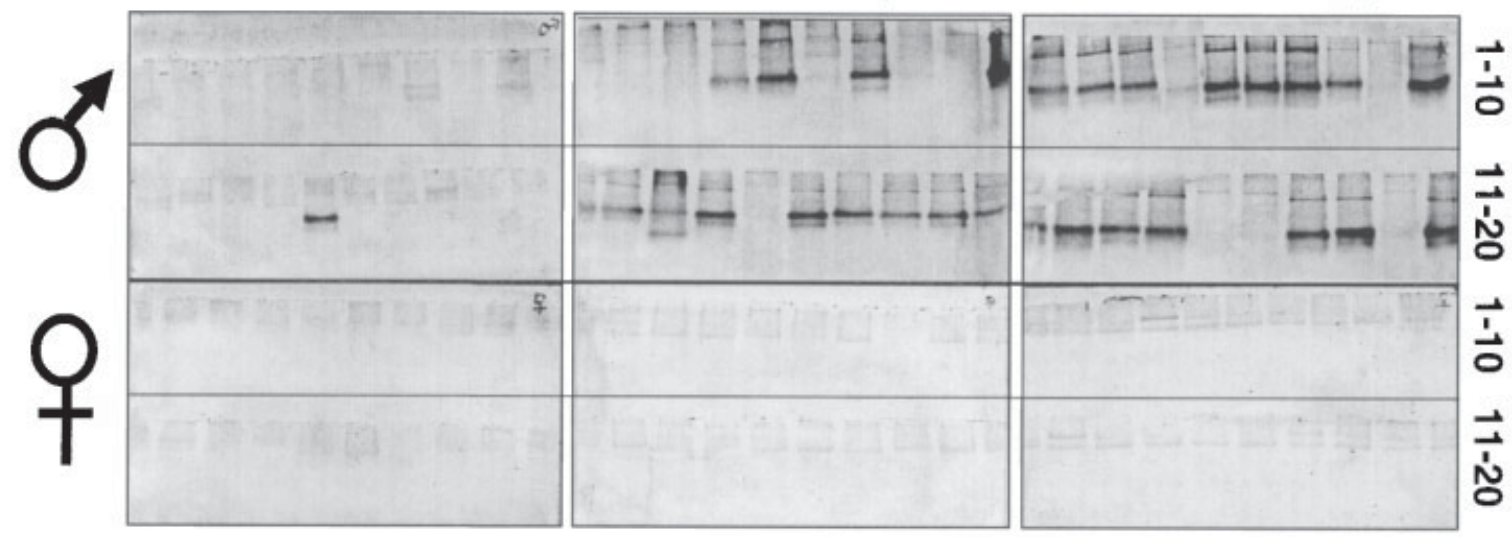

Fig. 2. Western blots of individual beetle protein extracts probed with 29-kDa antiserum (10 per gel, 20 per sex per population), following separation by native PAGE. The individual homogenates were prepared from the resistant York County $\left(R_{1}\right)$, Phelps County $\left(R_{2}\right)$, and susceptible Saunders County (S) populations. 
TABLE 1. Descriptions and Methyl-Parathion Susceptibility Levels of Populations Compared in Native PAGE and Western Blotting Studies

\begin{tabular}{lllc}
\hline Population no. & Collection site & County (state) & \% Mortality (SE) \\
\hline 1 & Mead & Saunders (NE) & $97.0(1.5)$ \\
2 & Collette & Yuma (CO) & $92.0(3.6)$ \\
3 & Johnson & Saunders (NE) & $80.3(4.9)$ \\
4 & Trumbull II & Clay (NE) & $70.0(7.3)$ \\
5 & Lochland & Adams (NE) & $69.5(9.7)$ \\
6 & Nelson & Phelps (NE) & $45.0(6.7)$ \\
7 & Colo-1 & Yuma (CO) & $44.0(9.5)$ \\
8 & Hampton & Hamilton (NE) & $32.0(7.7)$ \\
9 & Karrs & Adams (NE) & $22.8(7.2)$ \\
10 & Keene & Kearney (NE) & $13.3(4.6)$ \\
\hline
\end{tabular}

apercentage mortality in bioassays with a diagnostic concentration of methyl-parathion (see text for methods).

\section{DISCUSSION}

Following the partial purification of group II esterases, three putative esterase proteins $(20,29$, and $66-\mathrm{kDa}$ ) were enriched in resistant relative to susceptible populations. Two of these resistanceassociated proteins $(29-$ and $66-\mathrm{kDa})$ were purified to homogeneity and used as antigens to develop polyclonal antisera. The 29-kDa antibody recognized two lower molecular weight resistanceassociated proteins (20- and 29-kDa) but only in male beetles. The existence of a male-linked esterase (Est-m) in D. v. virgifera (Ruud et al., 1988; McDonald et al., 1990) with a molecular weight of approximately $78-\mathrm{kDa}$ and its activity localized in the abdomens of virgin males has been previously documented. The two male-linked proteins (20- and 29-kDa) identified in the present study are much smaller than Est-m, although Rudd et al. (1988) suggested the existence of other sex-linked loci in both $D$. v. virgifera and $D$. barberi. The role of these male-linked proteins is unclear, especially in relation to resistance, since there are no apparent differences in susceptibility to methyl-parathion between male and female beetles (Zhou, unpublished data), and no indication of sex-linked inheritance of esterase activity as determined by native PAGE analysis of individual rootworms obtained from reciprocal crosses (Parimi et al., 2003).

In contrast to the 29-kDa antiserum and based on multiple lines of evidence, the $66-\mathrm{kDa}$ antiserum is considered to be diagnostic for a group II esterase that is at least partially responsible for re-
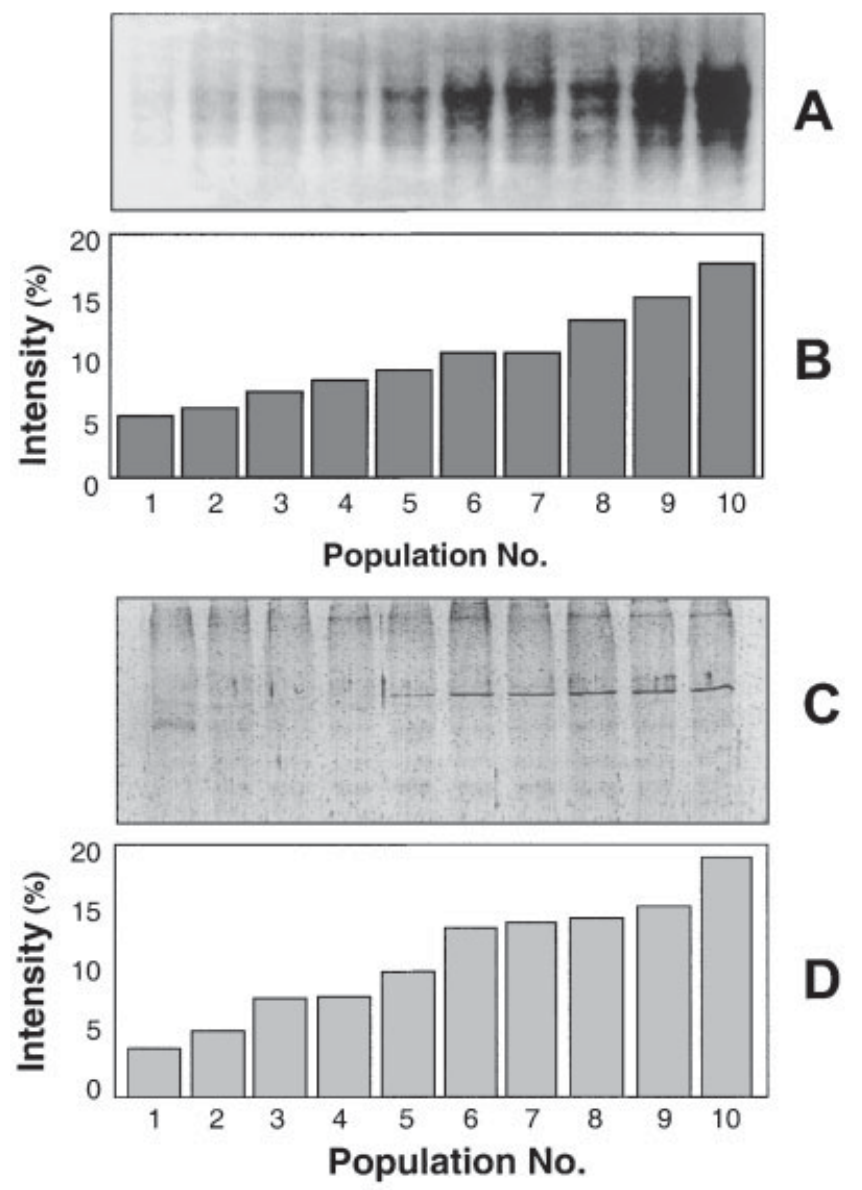

Fig. 3. Comparison of an immunological-based assay with a biochemical-based diagnostic native PAGE assay. A: Native PAGE assay result. B: Densitometric data corresponding to staining intensity shown in A ( $\alpha$-naphthyl acetate as substrate). C: Immunoassay result. D: Densitometric data corresponding to staining intensity shown in C (blot developed with BCIP-NBT substrate). A total of 10 D. $v$. virgifera populations with various susceptibilities to the diagnostic concentration of methyl-parathion (Table 1) are used to evaluate the diagnostic potential of the 66$\mathrm{kDa}$ specific immunoassay developed in this study.

TABLE 2. Regression Analyses Comparing \% Mortality in MethylParathion Diagnostic Concentration Bioassays (Table 1), Relative Intensity of Group II Esterase Activity (Visualized by Native PAGE Gels; Fig. 3B), and Relative Intensity of Immunological Response With 66-kDa Antiserum (Visualized by Western Blots; Fig. 3C)

\begin{tabular}{llrcc}
\hline Dependent variable & Independent variable & Slope & Y-intercept & $\mathrm{r}^{2 a}$ \\
\hline \% Mortality & PAGE relative intensity & -0.13 & 17.55 & 0.95 \\
\% Mortality & Western relative intensity & -0.17 & 19.92 & 0.96 \\
PAGE relative intensity & Western relative intensity & 1.28 & -2.96 & 0.95 \\
\hline
\end{tabular}

${ }^{a}$ Coefficient of determination indicating the goodness-of-fit of regression lines. 
sistance. Resistance-associated esterases may confer resistance either by qualitative modification of enzyme structure that increases catalytic efficiency or by quantitative modification that involves overproduction of esterases that act to sequester insecticidal esters (Hemingway, 2000). Based on the physical and biochemical properties of the partially purified group II esterase (66-kDa protein) (Zhou et al., 2004), we propose the overexpression of group II esterases as the underlying basis of esterase-mediated resistance in D. v virgifera. The immunoassay results shown here support this conclusion by demonstrating that increased titers of group II esterase proteins are associated with resistance.

We have previously shown that the Myzus persicae antiserum (Zhou et al. 2004) to the E4 esterase that confers organophosphate resistance in this aphid is cross-reactive with a $66-\mathrm{kDa}$ protein from both resistant and susceptible D. $v$. virgifera populations but that signal intensity was much stronger in preparations from resistant populations. It is highly likely that the resistance-associated E4 antiserum and $66-\mathrm{kDa}$ antiserum recognizes the same group II esterase (approximately $66-\mathrm{kDa}$ in size) from $D . v$ virgifera. Based on their immunological responses (signal intensity), group II esterases are immunologically indistinguishable between resistant and susceptible $D . v$. virgifera populations, and therefore different expression levels exhibited on immunoblots are a direct result of the overproduction of group II esterases in resistant populations. There are two types of genetic changes that may lead to this overproduction. The first is a stable, heritable change in the copy number of the gene (gene amplification) that would lead to the multiple gene copy numbers and increased levels of mRNA and protein. The second change involves modification of regulatory DNA sequences outside the protein coding region, which results in increased protein synthesis. Gene amplification has been conclusively documented in the aphids, Myzus persicae (esterases E4 and FE4) (Field et al., 1988; Field and Devonshire, 1998) and Schizaphis graminum (Type I esterases) (Siegfried et al., 1997; Ono et al., 1999), mosquitoes, Culex quinquefasciatus, C. pipens, C. tarsalis, and C. tritaeniorhynchus (esterases A and B) (Mouches et al.,1986;
Karunaratne et al., 1998; Hemingway et al., 1998), and brown planthoppers, Nilaparvata lugens (NIEST1) (Small and Hemingway, 2000). The combined results from biochemical, kinetic, and inhibition characterizations (Zhou et al., 2004), as well as immunological analyses (this study) imply an over-expression of the resistance-associated esterase in D. $v$. virgifera. However, it is not possible to determine whether such over-expression is due to gene amplification or a change in gene regulation that results in increased protein synthesis.

Immunological and biochemical-based techniques that diagnose both the qualitative and quantitative differences in detoxification enzymes offer tremendous opportunities to improve the speed, accuracy, and sensitivity of resistance monitoring (Denholm et al., 1990). Immunoassays for detecting resistant individuals have been developed for a number of insect pests and have been adapted to microplate format (such as Enzyme-linked immunosorbent assay, ELISA) for screening of large numbers of individuals in a relatively short period of time (Devonshire et al., 1986; Siegfried et al., 1997). In this report, immunological-based assays provide comparable results to both conventional diagnostic concentration bioassays as well as biochemical-based native PAGE assays. The low background exhibited by this technique (without contamination from other esterases) is a major advantage over biochemical-based native PAGE or model substrate assays. However, given that the 66$\mathrm{kDa}$ antiserum only recognizes denatured protein, development of immunological-based microplate assays (ELISA) for rapid detection of resistance would likely require further development. Once in place for routine execution, immunoassays in conjunction with diagnostic insecticide bioassays would provide a means to effectively monitor the onset of resistance development and to precisely document the distribution of resistant populations, with the end result being a better understanding of the effects of insecticide selection on resistance evolution.

\section{ACKNOWLEDGMENTS}

Emily Nekl provided a critical review of an earlier draft of this manuscript. Jim Brown and Jenny 
Stebbing helped collect and maintain $D . v$. virgifera field populations. Support for this project was provided by USDA Specific Cooperative Agreement 58-5447-6-116 and USDA Initiative for Future Agricultural and Food Science Grant No. 00-521039699. This Paper is contribution no. 14665 of the Journal Series of the Nebraska Agricultural Experiment Station and Contribution no. 1192 of the Department of Entomology.

\section{LITERATURE CITED}

Chang HC. 1973. Bionomics of the northern and western corn rootworms. Annu Rev Entomol 18:47-72.

Denholm I, Gorman KJ, Moores GD, Devonshire AL. 1990. Biochemical assays for insecticide resistance: strengths and limitations. Brighton Crop Prot Conf Pests Dis 3:11751180.

Devonshire AL, Moores GD, ffrench-Constant RH. 1986. Detection of insecticide resistance by immunological estimation of carboxylesterase activity in Myzus persicae (Sulter) and cross reaction of the antiserum with Phorodon humuli (Schrank) (Hemiptera: Aphididae). Bull Ent Res 76:97107.

Field LM, Devonshire AL, Forde BG. 1988. Molecular evidence that insecticide resistance in peach-potato aphids (Myzus persicae Sulz.) results from amplification of an esterase gene. Biochem J 251:309-312.

Field LM, Devonshire AL. 1998. Evidence that the E4 and FE4 esterase genes responsible for insecticide resistance in the aphid Myzus persicae (Sulzer) are part of a gene family. Biochem J 330:169-173.

Hemingway J. 2000. The molecular basis of two contrasting metabolic mechanisms of insecticide resistance. Insect Biochem Mol Biol 30: 1009-1015.

Hemingway J, Hawkes N, Prapanthadara L, Jayawardenal KG, Ranson H. 1998. The role of gene splicing, gene amplification and regulation in mosquito insecticide resistance. Philos Trans R Soc Lond B Biol Sci 353:1695-1699.

Karunaratne SHPP, Vaughan A Paton MG, Hemingway J. 1998. Amplification of a serine esterase gene is involved in insecticide resistance in Sri Lankan Culex tritaeniorhynchus. Insect Mol Biol 7:307-315.
Laemmli UK. 1970. Cleavage of structural proteins during the assembly of the head of bacteriophage T4. Nature 227:680685 .

Levine E, Oloumi-Sadeghi H. 1991. Management of Diabroticite rootworms in corn. Annu Rev Entomol 36:229-255.

Levine E, Spencer JL, Isard SA, Onstad DW, Gray ME. 2002. Adaptation of the western corn rootworm to crop rotation: evolution of a new strain in response to a management practice. Am Entomol 48:64-107.

McDonald IC, Krysan JL, Johnson OA. 1990. Studies of electrophoretic variation in Diabrotica as influenced by the age, sex, or diet of adult beetle (Coleoptera: Chrysomelidae). Ann Entomol Soc Am 83:1192-1202.

Meinke LJ, Siegfried BD, Wright RJ, Chandler LD. 1997. Western corn rootworm resistance to insecticides: current situation in Nebraska. Proc Illinois Agric Pestic Conf 88-92.

Meinke LJ, Siegfried BD, Wright RJ, Chandler LD. 1998. Adult susceptibility of Nebraska western corn rootworm (Coleoptera: Chrysomelidae) populations to selected insecticides. J Econ Entomol 91:594-600.

Miota F, Scharf ME, Ono M, Marcon P, Meinke LJ, Wright RJ, Chandler LD, Siegfried BD. 1998. Mechanisms of methyl and ethyl-parathion resistance in the western corn rootworm (Coleoptera: Chrysomelidae). Pestic Biochem Physiol 61:39-52.

Mouches C, Pasteur N, Berge JB, Hyrien O, Raymond M, De Saint Vincent BR, De Silvestri M, Georghiou GP. 1986. Amplification of an esterase gene is responsible for insecticide resistance in a California Culex mosquito. Science 233:778-780

Ono M, Swanson JJ, Field LM, Devonshire AL, Siegfried BD. 1999. Amplification and methylation of an esterase gene associated with insecticide-resistance in greenbugs, Schizaphis graminum (Rondani) (Homoptera: Aphididae). Insect Biochem Mol Biol 29:1065-1073.

Parimi S, Scharf ME, Meinke LJ, Chandler LD, Siegfried BD. 2003. Inheritance of methyl-parathion resistance in $\mathrm{Ne}$ braska western corn rootworm populations (Coleoptera: Chrysomelidae). J Econ Entomol 96:131-136.

Pruess KP, Witkowski JF, Raun ES. 1974. Population suppression of western corn rootworm by adult control with ULV malathion. J Econ Entomol 67:651-655. 
Ruud SK, McDonald IC, Gabrielson DA, Johnson OA. 1988. Species distribution and characterization studies of sexlimited esterases within the virgifera group of Diabrotica (Coleoptera: Chrysomelidae). Ann Entomol Soc Am 81:954-963.

SAS Institute. 2001. SAS user's guide: statistics. Cary, NC: SAS Institute

Siegfried BD, Swanson JJ, Devonshire AL. 1997. Immunological detection of greenbug (Schizaphis graminum) esterases associated with resistance to organophosphate insecticides. Pestic Biochem Physiol 57:165-170.

Small GJ, Hemingway J. 2000. Molecular characterization of the amplified carboxylesterase gene associated with organophosphorus insecticide resistance in the brown planthopper, Nilaparvata lugens. Insect Mol Biol 9:647-653.

Wright RJ, Scharf ME, Meinke LJ, Zhou X, Siegfried BD, Chandler LD. 2000. Larval susceptibility of an insecticide-resistant western corn rootworm (Coleoptera: Chrysomelidae) population to soil insecticides: laboratory bioassays, assays of detoxification enzymes, and field performance. J Econ Entomol 93:7-13.

Zhou X, Scharf ME, Parimi S, Meinke LJ, Wright RJ, Chandler LD, Siegfried BD. 2002. Diagnostic assays based on esterase-mediated resistance mechanisms in western corn rootworms (Coleoptera: Chrysomelidae). J Econ Entomol 95:1261-1266.

Zhou X, Scharf ME, Meinke LJ, Chandler LD, Siegfried BD. 2003. Characterization of general esterases from methylparathion resistant and susceptible populations of western corn rootworm (Coleoptera: Chrysomelidae). J Econ Entomol 96:1855-1863.

Zhou X, Scharf ME, Sarath G, Meinke LJ, Chandler LD, Siegfried BD. 2004. Partial purification and characterization of a methyl-parathion resistance-associated general esterase in Diabrotica virgifera virgifera (Coleoptera: Chrysomelidae). Pestic Biochem Physiol 78:114-125. 